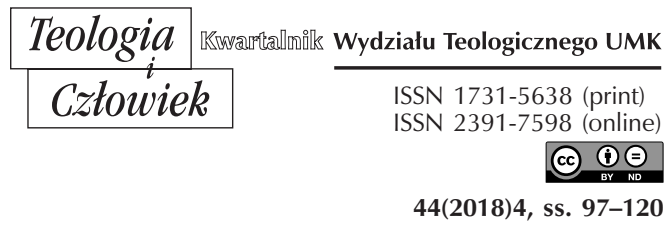

KS. KRZYSZTOF ROGALA

WYDZIAK PRAWA KANONICZEGO UKSW W WARSZAWIE

ROGALAKRZYSZTOF@WP.PL

ORCID: 0000-0003-4914-6855

\title{
RADA KAPŁAŃSKA JAKO PRZEJAW KOLEGIALNOŚCI $W$ KOŚCIELE PARTYKULARNYM NA PRZYKŁADZIE DIECEZJI WŁOCŁAWSKIEJ
}

DOI: http://dx.doi.org/10.12775/TiCz.2018.041

Streszczenie. Reforma Soboru Watykańskiego II podjęła refleksję Kościoła o sobie samym. Owocem tych działań stała się odnowiona eklezjologia. Zwrócono uwagę na zagadnienia związane z pasterską troską biskupów o swoje Kościoły partykularne. Podjęto także wnikliwą analizę zrozumienia teologii kapłaństwa i relacji, jaka zachodzi pomiędzy biskupem i jego prezbiterium. W wyniku tych rozważań zostały odnowione te już istniejące, a także powołane do istnienia nowe organy konsultacyjne w Kościołach partykularnych. Jednym z tych organów, które zostały powołane do istnienia dzięki reformie soborowej, jest rada kapłańska. Artykuł prezentuje, w jaki sposób ten nowy organ Kościoła partykularnego został wdrożony w Diecezji włocławskiej. Ukazane zostało działanie kolejnych biskupów włocławskich dokonujących recepcji prawa powszechnego na terenie swojej diecezji w tej materii.

Słowa kluczowe: rada kapłańska; diecezja włocławska; kolegialność w Kościele partykularnym; organy konsultacyjne.

Abstract. The Pastoral Council as Indication of Collegiality in The Particular Church by the Example of the Roman Catholic Diocese of Włocławek. The reform of Second Vatican Council contemplated about the Church. The fruition of these actions was the renewed ecclesiology. The issues connected with pastoral care about their particular 
Churches were taken into consideration. Careful analysis of understanding the theology of priesthood and relation between the bishop and its presbyterium were also discussed. As the result of these considerations consultative bodies in the particular Church were renewed and some new were formed. One of these bodies is the pastoral council. The article presents the way of implementing this new body to The Roman Catholic Diocese of Włocławek. The further Włocławek bishops' activities who introduced common law into their dioceses were shown.

Key words: Pastoral Council; The Roman Catholic Diocese of Włocławek; Collegiality in the particular Church; Consultative bodies.

\section{WSTĘP}

Reforma Soboru Watykańskiego II pozwoliła na podjęcie refleksji Kościoła o sobie samym. Owocem tych działań stała się odnowiona eklezjologia. Zwrócono uwagę na zagadnienia związane z pasterską troską biskupów o swoje Kościoły partykularne. Podjęto także wnikliwą analizę zrozumienia teologii kapłaństwa i relacji, jaka zachodzi pomiędzy biskupem i jego prezbiterium. W wyniku tych rozważań zostały odnowione, te już istniejące, a także powołane do istnienia nowe organy konsultacyjne w Kościołach partykularnych.

Jednym z tych organów, które zostały powołane do istnienia dzięki reformie soborowej, jest Rada kapłańska. Można zatem postawić pytanie, czy i w jaki sposób ten nowy organ Kościoła partykularnego został wdrożony w poszczególnych Kościołach partykularnych, a co za tym idzie, jak poszczególni biskupi dokonali recepcji prawa powszechnego na terenie swoich diecezji w tej materii. Niniejsze opracowanie będzie poszukiwaniem odpowiedzi na postawione pytanie, analizując szczegółowo działalność biskupów diecezji włocławskiej.

Materiał zostanie zaprezentowany w trzech częściach. Pierwsza, wstępna ukaże przejawy kolegialności w Kościele partykularnym, podając ich teologiczne podstawy. Druga część przedstawi kształtowanie się prawodawstwa powszechnego w zakresie rady kapłańskiej od Soboru Watykańskiego II aż po kodyfikację w 1983 roku. Ostatnią częścią będzie analiza ustawodawstwa diecezji włocławskiej w odniesieniu do prawa powszechnego dotyczącego omawianej materii. Wnioski końcowe pozwolą odpowiedzieć na postawione wcześniej pytanie. 


\section{PRZEJAWY KOLEGIALNOŚCI W KOŚCIELE PARTYKULARNYM}

Jeden i jedyny Kościół katolicki, który obejmuje cały Lud Boży, składa się z Kościołów partykularnych, w których to istnieje, objawia się i prowadzi swoją działalność ${ }^{1}$. Kodeks prawa kanonicznego ${ }^{2}$ definiuje diecezję̧, czyli Kościół partykularny jako część Ludu Bożego, powierzoną pasterskiej pieczy biskupa, który pozostaje w jedności z papieżem i Kolegium biskupów. Wspólnota ta posiada własne prezbiterium i wiernych świeckich ${ }^{4}$.

Biskup jako głowa diecezji i uczestnik władzy wspólnej innych biskupów w łączności z Biskupem Rzymu jest zewnętrznym wyrazem jednoczenia się Kościoła powszechnego z Kościołem partykularnym. Sprawuje on w swojej diecezji potrójną władzę: ustawodawczą, wykonawczą i sądowniczą. W wykonywaniu tej władzy korzysta z pomocy określonych w prawie organów - instytucji i osób, które tworzą struktury kolegialne i wypełniają zlecone im zadania ${ }^{5}$. Organy wspomagające biskupa diecezjalnego $\mathrm{w}$ trosce o potrzeby powierzonego mu Kościoła partykularnego mogą być jednoosobowe lub kolegialne. Organy jednoosobowe to np. wikariusz generalny, wikariusz biskupi (wspierają w wykonywaniu władzy administracyjnej), wikariusz sądowy (wspiera w wykonywaniu władzy sądowniczej). Organy kolegialne składają się z wielu osób fizycznych, mogą to być tylko duchowni bądź duchowni i świeccy ${ }^{6}$.

Obecność w Kościołach partykularnych kolegialnych organów jest wynikiem refleksji Kościoła o sobie samym jako wspólnocie Ludu Bożego

1 J. Glemp, Problem identyfikacji Kościoła lokalnego i partykularnego, „Prawo Kanoniczne" 21 (1978) 3-4, s. 37-38.

2 Codex Iuris Canonici auctoritate Ioannis Pauli PP. II promulgatus, 25 I 1983; tekst polski w: Kodeks prawa kanonicznego, Poznań 1984, w dalszej części: KPK 1983 r.

3 Kan 368 KPK 1983 traktuje o tym, iż z diecezją zrównane są prałatury i opactwa terytorialne, wikariaty apostolskie i prefektury apostolskie oraz administratury apostolskie erygowane na sposób stały.

${ }^{4}$ Kan. 369 KPK 1983.

5 W. Góralski, Struktury synodalne i kolegialne w Kościele partykularnym według KPK Jana Pawła II, „Studia Płockie” XIV (1986), s. 54.

${ }^{6}$ J. Krukowski, Kolegialne organy konsultacyjne w Kościołach partykularnych, w: Struktury kolegialne w Kościele partykularnym, J. Krukowski, T. Rozkrut (red.), Tarnów 2004, s. 24. 
i społeczności posiadającej organy hierarchiczne, która dokonała się na Soborze Watykańskim II ${ }^{7}$. Podstawę stanowią przesłanki teologiczne, znajdujące się w dokumentach soborowych. Pierwsza z nich dotyczy przyjęcia prawdy, że wszyscy wierni na mocy sakramentu chrztu są powołani do współpracy i współodpowiedzialności w zbawczej misji Chrystusa oraz w budowaniu wspólnoty kościelnej ${ }^{8}$. Kolejną przesłanką jest uznanie prawa wiernych świeckich do tego, by mogli wypowiadać swoje zdanie w sprawach dotyczących Kościoła za pośrednictwem odpowiednich instytucji, które zostały do tego celu powołane, a biskupi zostali wezwani, by $\mathrm{z}$ tych rad chętnie korzystali ${ }^{9}$. Trzecia zobowiązuje do uznania zasady, że narzędziem współpracy pomiędzy duchownymi i świeckimi na płaszczyźnie diecezjalnej powinna być rada duszpasterska ${ }^{10}$. Ostatnią przesłanką jest uznanie prawdy, iż wszyscy kapłani wraz ze swoimi biskupami mają udział w jednym i tym samym kapłaństwie i posłudze Chrystusa. Tworząc z nim prezbiterium diecezjalne, są niezbędnymi pomocnikami i doradcami swojego biskupa w posłudze nauczania i kierowania Ludem Bożym, oraz są odpowiedzialni za dobro swojego Kościoła diecezjalnego ${ }^{11}$. W tym celu wskazano potrzebę utworzenia rady kapłańskiej jako senatu biskupa, reprezentującego ogół prezbiterów diecezji, mający na celu wspieranie biskupa swoimi radami w jego rządach ${ }^{12}$.

Jeśli chodzi o organy kolegialne w Kościele partykularnym, powołane $\mathrm{w}$ celu niesienia pomocy biskupowi diecezjalnemu w wykonywaniu jego posługi, to oprócz tych, które znane były już w pierwszych wiekach

${ }^{7}$ J. Krukowski, Administracja w Kościele, Zarys kościelnego prawa administracyjnego, Lublin 1985, s. 15-16.

${ }^{8}$ Sobór Watykański II, Konstytucja dogmatyczna o Kościele Lumen gentium nr 10 i 31 .

9 Tamże, Konstytucja dogmatyczna o Kościele Lumen gentium nr 37, Dekret o pasterskich zadaniach biskupów w Kościele Christus Dominus nr 23; J. Dyduch, Obowiązki i prawa wiernych świeckich w prawodawstwie soborowym, Kraków 1985, s. 156.

10 Sobór Watykański II, Dekret o pasterskich zadaniach biskupów w Kościele Christus Dominus nr 27, Dekret o misyjnej działalności Kościoła Ad gentes divinitus nr 30.

11 Sobór Watykański II, Dekret o posłudze i życiu prezbiterów Prezbiterorum ordinis nr 38; Konstytucja dogmatyczna o Kościele Lumen gentium nr 28.

12 Tamże, Dekret o posłudze i życiu prezbiterów Presbyterorum ordinis $\mathrm{nr} 7$, J. Wroceński, Rola i zadania prezbiterium w życiu Kościoła partykularnego, Warszawa 1998, s. 313-314. 
istnienia Kościoła (synod diecezjalny) oraz tych późniejszych z wieków średnich (kapituła kanonicka), wiele nowych form otrzymało swoje fundamenty na Soborze Watykańskim $\mathrm{II}^{13}$.

W obecnie obowiązującym prawie do obligatoryjnych kolegialnych organów konsultacyjnych w Kościołach partykularnych zaliczają się: synod diecezjalny, Rada kapłańska, kolegium konsultorów, rada duszpasterska, rada do spraw ekonomicznych. Ponadto każdy biskup może powołać także inne organy kolegialne, w zależności od potrzeb swojej diecezji, np. radę społeczną, radę do spraw kultury ${ }^{14}$.

W dalszej części niniejszego opracowania zostanie ukazana troska prawodawcy kościelnego o utworzenie i unormowanie się w przepisach prawa instytucji kolegialnej Kościoła partykularnego, jaką jest Rada kapłańska.

\section{RADA KAPŁAŃSKA W DOKUMENTACH KOŚCIOŁA}

Dokumenty traktujące o radzie kapłańskiej można podzielić na trzy zasadnicze grupy: dokumenty Soboru Watykańskiego II, ustawodawstwo posoborowe oraz Kodeks prawa kanonicznego z 1983 roku.

\section{DOKUMENTY SOBORU WATYKAŃSKIEGO II}

Ustawodawstwo soborowe podaje teologiczne oraz dogmatyczne podstawy zasadności istnienia rady kapłańskiej w następujących dokumentach: Konstytucja dogmatyczna o Kościele Lumen gentium (nr 28), Dekret o pasterskich zadaniach biskupów w Kościele Christus Dominus (nr 16, 27, 28), Dekret o posłudze i życiu kapłanów Presbyterorum Ordinis (nr 15), Dekret o działalności misyjnej Kościoła Ad gentes divinus (nr 20) ${ }^{15}$. Wymienione dokumenty nie mówią wprost o powstaniu

${ }_{13}$ W. Góralski, Struktury synodalne i kolegialne w Kościele partykularnym według KPK Jana Pawła II, art. cyt. s. 54.

${ }^{14}$ J. Krukowski, Kolegialne organy konsultacyjne w Kościołach partykularnych, s. 24-25.

15 J. Borucki, Rada Kapłańska wyrazem udziału prezbiterów w życiu Kościoła partykularnego, „Ateneum Kapłańskie” 134 (2000), z. 2 (546), s. 445. 
nowej instytucji prawnej, a raczej pośrednio stwarzają dla niej tylko podstawy.

Jedynie Dekret o posłudze i życiu kapłanów Presbyterorum Ordinis $\mathrm{w} \mathrm{nr} 7$, podejmuje bezpośrednio zagadnienie powstania rady kapłańskiej:

By zaś to doprowadzić do skutku niech mają radę, czyli senat kapłanów, reprezentujących ogół prezbiterów, który dostosowany do dzisiejszych okoliczności i potrzeb $\mathrm{w}$ formie i według norm prawnych, mógłby skutecznie wspierać biskupa swymi radami w rządzeniu diecezją ${ }^{16}$.

W przytoczonym fragmencie znajduje się całość treści normatywnej, podjętej przez Sobór dotyczącej instytucjonalnego udziału prezbiterów w kierowaniu diecezją. Nauczanie Soboru ogranicza się tylko do określenia ogólnego pojęcia i zadania rady kapłańskiej oraz do ukazania potrzeby jej istnienia w Kościele partykularnym ${ }^{17}$.

\section{DOKUMENTY POSOBOROWE}

Jeśli chodzi o poszczególne i konkretne zadania spoczywające na Radzie kapłańskiej, to dopiero nauczanie posoborowe i nowy Kodeks zajęły szczegółowe stanowisko w tej materii. Podczas Soboru została zakreślona jedynie koncepcja i struktura tego nowego organu, a szczegółowe normy jej funkcjonowania miało określić prawo ${ }^{18}$.

Pierwszym dokumentem wydanym po zakończeniu Soboru, traktującym o radzie kapłańskiej, było motu proprio Pawła VI Ecclesiae sanctae $^{19}$, stanowiące normy wykonawcze do Dekretu Presbyterorum Ordinis. Zostały one wydane ad experimentum, do czasu powstania nowego prawodawstwa kościelnego. Ten niejako doświadczalny charakter tego dokumentu wymagał, aby przepisy w nim zawarte jak najszybciej wpro-

16 Sobór Watykański II, Dekret o posłudze i życiu prezbiterów Presbyterorum Ordinis nr 7.

${ }_{17}$ J. Wroceński, Rola i zadania prezbiterium w życiu Kościoła partykularnego, s. $282-283$.

18 W. Wójcik, Rada Kapłańska, „Ateneum Kapłańskie” 71 (1968), s. 221.

19 Normy te zostały ogłoszone 6.08.1966 r. 
wadzić w życie, w celu uzyskania odpowiedniego doświadczenia przed ostatecznym utworzeniem norm dotyczących rady kapłańskiej w nowym Kodeksie $^{20}$. Dokument ten nakładał obowiązek utworzenia w każdej diecezji rady kapłańskiej, a o jej kształcie i sposobie działania miał decydować biskup ${ }^{21}$. Obowiązek utworzenia nowego kościelnego organu został nałożony na inne Kościoły partykularne prawnie zrównane z diecezją, których pasterze są prawnie zrównani z biskupem diecezjalnym ${ }^{22}$. Ecclesiae sanctae pozostawiało w gestii biskupa i konferencji biskupów wypracowanie szczegółowych przepisów odnoszących się do struktury rady kapłańskiej ${ }^{23}$. Rozstrzygnięto także kwestię przynależności do rady kapłanów zakonnych. Mogą oni być jej członkami, jeżeli otrzymali od biskupa diecezjalnego misję, dzięki której współpracują w duszpasterstwie, bądź pełnią inne zlecone im zadania apostolatu, współpracując z prezbiterium tejże diecezji ${ }^{24}$.

Po trzech latach od ogłoszenia motu proprio Ecclesiae sanctae, Kongregacja do spraw duchowieństwa, której podlegają rady kapłańskie, skierowała do przewodniczących konferencji biskupich prośbę, aby przesłali oni swoje spostrzeżenia i uwagi dotyczące funkcjonowania na ich terenach tego nowego organu kościelnego ${ }^{25}$. Owocem tej dyskusji stał się List okólny Presbyteri sacra, wydany przez tę kongregację 11.04.1970 r. Nie miał on charakteru ustawy ani nie był nakazem prawnym, ale zarządzeniem administracyjnym odnoszącym się do ustawy soborowej i papieskiej ${ }^{26}$. W treści omawianego listu w sposób bardziej szczegółowy zamieszczono wskazania dotyczące reprezentowalności w tejże radzie. Podkreślony został zapis, aby w składzie rady kapłańskiej znajdowali się

20 T. Pieronek, Rada Kapłańska wyrazem soborowej odnowy prezbiterium, „Prawo Kanoniczne" 12 (1969) 3-4, s. 17.

${ }^{21}$ W. Wójcik, Rada Kapłańska, s. 221.

${ }^{22}$ J. Borucki, Rada Kapłańska wyrazem udziału prezbiterów w życiu Kościoła partykularnego, s. 447-448.

${ }^{23}$ J. Wroceński, Rola i zadania prezbiterium w życiu Kościoła partykularnego, s. 290 .

${ }^{24}$ M. Fąka, Rada kapłańska nowym senatem biskupa diecezjalnego, „Prawo Kanoniczne" 21 (1978) 3-4, s. 52-53.

25 Tamże, s. 44.

${ }^{26}$ J. Borucki, Kapituła katedralna i Rada Kapłańska - stary i nowy senat biskupa diecezjalnego, „Studia Włocławskie” 9 (2009), s. 252. 
przedstawiciele całego prezbiterium diecezjalnego. Dlatego powinni zostać powołani w jej skład kapłani z różnych okręgów duszpasterskich, przedstawiający różne generacje i posługi. Gdyby były trudności z uwzględnieniem omawianych kryteriów, pierwszeństwo ma różnorodność posług. Dokument ten mówi także o tym, że sposób wyboru pozostaje w uznaniu biskupa ${ }^{27}$. Ponadto $\mathrm{w}$ Liście okólnym zamieszczone zostały wskazania dotyczące zakresu spraw, którymi miała zajmować się Rada kapłańska, a mianowicie wszystkimi sprawami dotyczącymi duszpasterstwa oraz sprawami dotyczącymi ogólnego zarządzania diecezją, o ile biskup przedłoży wcześniej bądź wyrazi zgodę na ich rozpatrzenie przy zachowaniu przepisów prawa powszechnego ${ }^{28}$.

Kolejnym aktem posoborowym odnoszącym się do omawianej materii był Dokument Synodu Biskupów z 1971 roku o kapłaństwie służebnym De sacerdotio ministeriali. Nie stanowi on normy obowiązującej pod względem prawnym, ale nie jest on także powtórzeniem tego co było powiedziane na Soborze i w dokumentach późniejszych. Zawierał konkretne instrukcje i wytyczne dla prawnego uformowania rady kapłańskiej w przyszłości ${ }^{29}$.

Ostatnim dokumentem przed promulgacją nowego Kodeksu, odnoszącym się do nowego senatu biskupa, jest Instrukcja Kongregacji ds. Biskupów na temat pasterskiej posługi biskupów Ecclesiae imago z dnia 22.02.1973 r. Stała się ona urzędową pomocą w wykładni wszystkich norm soborowych jak i późniejszych odnoszących się do rady kapłańskiej ${ }^{30}$. Zasadniczo nie wnosiła nic nowego, jeśli chodzi o strukturę osobową, a wiele zapisów w niej zawartych było powtórzeniem wcześniejszych postanowień albo były one bardzo podobne ${ }^{31}$. Zawarto w niej wytyczne i nakreślono linie przewodnie odnośnie do utworzenia i działania

27 J. Wroceński, Rola i zadania prezbiterium w życiu Kościoła partykularnego, s. $290-291$.

${ }^{28}$ J. Borucki, Rada Kapłańska wyrazem udziału prezbiterów w życiu Kościoła partykularnego, s. 449.

${ }^{29}$ M. Fąka, Rada kapłańska nowym senatem biskupa diecezjalnego, s. 52-45-46.

${ }^{30}$ J. Borucki, Kapituła katedralna i Rada Kapłańska - stary i nowy senat biskupa diecezjalnego, s. 252.

${ }^{31}$ J. Wroceński, Rola i zadania prezbiterium w życiu Kościoła partykularnego, s. 292. 
tego organu ${ }^{32}$. W omawianej instrukcji sprecyzowano kompetencje rady kapłańskiej. Zamieszczono je w następującej kolejności: sprawy życia kapłańskiego (świętość kapłańska, formacja intelektualna, inne potrzeby kapłanów); posługa uświecania i religijnego kształtowania wiernych; ogólne zarządzanie diecezją pod kątem kapłańskiego posługiwania dla dobra całej wspólnoty Kościoła partykularnego ${ }^{33}$.

\section{RADA KAPŁAŃSKA W PRZEPISACH KODEKSU PRAWA KANONICZNEGO Z 1983 ROKU.}

Zwieńczeniem kształtowania prawodawstwa kościelnego po Soborze Watykańskim II, stała się promulgacja Kodeksu prawa kanonicznego w 1983 r., o którym Jan Paweł II w konstytucji Sacre disciplinae leges promulgującej Kodeks wyraził się, iż „może być pojmowany jako wielki pas transmisyjny przenoszący na język kanonistyczny tę doktrynę, mianowicie soborową eklezjologię".

Zamknięcie pewnego etapu kształtowania się przepisów ustawodawstwa soborowego i posoborowego odnośnie rady kapłańskiej znalazło w Kodeksie odzwierciedlenie w postaci ośmiu kanonów (495-502) znajdujących się w II księdze, części II, sekcji II, tytule III, rozdziale III zatytułowanym „Rada kapłańska i kolegium konsultorów”.

Kanon $495 \$ 1$ brzmi:

W każdej diecezji winna być ustanowiona Rada kapłańska, czyli zespół kapłanów, będący jakby senatem biskupa i reprezentującym prezbiterium. Jej zadaniem jest wspieranie biskupa w zarządzaniu diecezji, zgodnie z przepisami prawa, ażeby możliwie najbardziej pomnażało się dobro pasterskie powierzonej mu porcji Ludu Bożego.

Pierwszy z kanonów odnoszących się do rady kapłańskiej określa jej pojęcie zobowiązuje biskupa do jej ustanowienia, a także podaje jej

32 M. Fąka, Rada kapłańska nowym senatem biskupa diecezjalnego, s. 46.

${ }^{33}$ J. Borucki, Rada Kapłańska wyrazem udziału prezbiterów w życiu Kościoła partykularnego, s. 449. 
cele $^{34}$. Jeśli chodzi o pojęcie „senat biskupa”, to w poprzednim Kodeksie z roku 1917, a także w dokumentach soborowych (Christus Dominus) nazywano tak kapitułę katedralną. Dopiero po piśmie okólnym do przewodniczących Konferencji Biskupów z 11.04.1970 roku wydanego przez Kongregację do spraw Duchowieństwa wyjaśniono, iż tytuł senatu biskupa przysługuje wyłącznie Radzie kapłańskiej ${ }^{35}$. Treść cytowanego kanonu ukazuje obligatoryjny obowiązek ustanowienia tego organu w każdej diecezji ${ }^{36}$. Ustanowienie jej staje się znakiem i instytucjonalną formą współodpowiedzialności w pasterskiej posłudze biskupa i jego prezbiterów ${ }^{37}$. Do celów Rady kapłańskiej można zaliczyć dwie podstawowe funkcje. Pierwszą jest popieranie wspólnoty prezbiterium jaka zachodzi pomiędzy prezbiterami i biskupem oraz między prezbiterami wzajemnie, ma ona znaleźć swój wyraz w duchu braterskiej solidarności. Natomiast drugą jest konkretna pomoc biskupowi w zarządzaniu diecezją ${ }^{38}$.

Kolejny przepis traktuje, iż Rada kapłańska powinna posiadać własne statuty, które zatwierdza biskup diecezjalny po uwzględnieniu norm wydanych wcześniej przez konferencję episkopatu ${ }^{39}$. Zgodnie z omawianym kanonem, statuty te powinny uwzględniać i dostosować do warunków diecezjalnych odpowiednie przepisy prawa powszechnego, a także akty prawne wydane przez konferencje biskupie. W przepisach kodeksowych nie ma nic na temat tego, kto ma być autorem statutów.

${ }^{34}$ M. Sitarz, Rada Kapłańska i Kolegium Konsultorów, w: Komentarz do Kodeksu prawa kanonicznego, Tom II cz. 1, Ksiega II. Lud Boży, J. Krukowski (red.), Poznań 2005, s. 384.

${ }^{35}$ J. Borucki, Rada Kapłańska wyrazem udziału prezbiterów w życiu Kościoła partykularnego, s. 450-451.

${ }^{36}$ Według $₫ 2$ kan. 495, nie ma tego obowiązku w Kościołach partykularnych znajdujących się na terenach misyjnych takich jak wikariat apostolski i prefektura apostolska, które z pewnych względów nie zostały jeszcze ukonstytuowane jako diecezja. Natomiast odpowiedzialni za ich kierowanie mają obowiązek utworzenia innego organu kolegialnego składającego się z co najmniej 3 prezbiterów. Zob. M. Sitarz, Rada Kapłańska i Kolegium Konsultorów, s. 384.

37 J. Wroceński, Rada Kapłańska według Kodeksu prawa kanonicznego, „Prawo Kanoniczne" 36 (1993) 1-2, s. 22-23.

38 E. Górecki, Rada Kapłańska, w: Struktury kolegialne w Kościele partykularnym, J. Krukowski, T. Rozkrut (red.), Tarnów 2004, s. 84-85.

39 Kan. 496 KPK 1983. 
W myśl dokumentów posoborowych wypada, aby treść statutów została przygotowana przez samą Radę kapłańską ${ }^{40}$. Biskup diecezjalny zatwierdza te statuty oraz gdyby nastąpiła w nich jakaś zmiana, to również wymagana jest jego aprobata ${ }^{41}$.

Prawodawca kodeksowy w kolejnych trzech kanonach (497-499) podejmuje zagadnienie członkostwa $\mathrm{w}$ Radzie kapłańskiej oraz prawa i sposobu wyboru na tychże członków.

Pierwsze z zagadnień znajdujące się w kanonie 497 KPK 1983 ma swoje źródło w Presbyterorum ordinis, gdzie jest mowa o tym, iż omawiany organ powinien reprezentować przekrój całego prezbiterium diecezjalnego i składać się z trzech grup kapłanów. Mianowicie tych z wyboru, $\mathrm{z}$ urzędu i z nominacji. Ich liczba powinna wynosić w zależności od wielkości diecezji między 15 a 40 członków ${ }^{42}$. Jeśli chodzi o kapłanów z wyboru dokonanego przez całe prezbiterium, to powinni oni stanowić połowę członków, z czego co najmniej połowa z nich powinna być proboszczami ${ }^{43}$. Kapłani z urzędu to ci, którzy powinni przynależeć do rady kapłańskiej ze względu na pełnioną przez nich funkcję. Ustawa nie podaje jakie to funkcje i urzędy, pozostawia to w gestii statutów ${ }^{44}$. Według postanowień Konferencji Episkopatu Polski ${ }^{45}$ z urzędu wchodzą: biskup koadiutror, biskupi pomocniczy, wikariusze generalni i biskupi, kapłan kierujący wydziałem duszpasterskim w diecezji, rektor wyższego seminarium duchownego oraz przewodniczący kapituły katedralnej ${ }^{46}$. Ostatnią grupę członków senatu biskupa stanowią kapłani z nominacji. Aby zapewnić pełną reprezentatywność radzie, biskup powinien zatroszczyć się o to, by wśród jej członków znaleźli

${ }^{40}$ J. Wroceński, Rada Kapłańska według Kodeksu prawa kanonicznego, s. 25-26.

${ }^{41}$ T. Pawluk, Prawo kanoniczne według Kodeksu Jana Pawła II, t. 2, Olsztyn 1986, s. 238.

${ }^{42}$ E. Górecki, Rada Kapłańska, w: Struktury kolegialne w Kościele partykularnym, s. $84-85$.

${ }^{43}$ M. Sitarz, Rada Kapłańska i Kolegium Konsultorów, s. 386.

${ }^{44}$ J. Borucki, Rada Kapłańska wyrazem udziału prezbiterów w życiu Kościoła partykularnego, s. 451-452.

45 Postanowienia Konferencji Episkopatu Polski w sprawie Rad Kapłańskich i Kolegium Konsultorów z dnia 21.03.1985 roku.

46 E. Górecki, Rada Kapłańska, s. 86. 
się także specjaliści z różnych dziedzin, którzy nie zawsze mogliby być wybrani ${ }^{47}$.

Prawo wyboru zarówno czynne, jak i bierne przysługuje wszystkim kapłanom inkardynowanym do danej diecezji, tym, którzy nie są do niej inkardynowani, ale przebywają na jej terenie i wykonują jakiś urząd dla jej dobra (zarówno kapłani diecezjalni, jak i członkowie instytutów życia konsekrowanego lub stowarzyszeń życia apostolskiego), a także jeżeli zezwolą na to statuty inni kapłani mający stały lub tymczasowy pobyt na terenie diecezji ${ }^{48}$. W skład Rady kapłańskiej mogą wchodzić duchowni, którzy są kapłanami, a co za tym idzie, nie mogą należeć do niej ani diakoni, ani osoby konsekrowane, które nie mają święceń prezbiteratu. Ten, kto nie może być członkiem tego organu, nie ma również prawa wyboru ${ }^{49}$.

Statuty poszczególnych rad powinny określać sposób wyboru ich członków z uwzględnieniem, by przedstawiciele całego prezbiterium mieli swoich reprezentantów, zwłaszcza jeśli chodzi o różnorodność pełnionych posług oraz różne rejony diecezji ${ }^{50}$. W myśl tego kanonu, w miarę możliwości w składzie członków Rady kapłańskiej powinni znajdować się przedstawiciele proboszczów, wikariuszy, dziekanów, profesorów seminarium itp. Ponadto bardzo ważnym kryterium jest także terytorialność, czyli by znajdowali się $\mathrm{w}$ niej także przedstawiciele różnych rejonów diecezji. Innym kryterium jest różnorodność pokoleń kapłańskich. Do najważniejszych jednak należą urzędy kapłańskie i okręgi duszpasterskie ${ }^{51}$.

Kanon 500 podaje normy odnośnie do pozycji biskupa diecezjalnego w Radzie kapłańskiej. Biskup diecezjalny jako głowa prezbiterium zwołuje posiedzenie Rady kapłańskiej, przewodniczy jej, a także określa sprawy, które będą rozpatrywane lub dopuszcza te zgłoszone przez członków $^{52}$. Paragraf drugi omawianego kanonu podkreśla, iż Rada kapłańska ma tylko głos doradczy. W niektórych sytuacjach dopuszczonych przez

${ }^{47}$ J. Wroceński, Rada Kapłańska według Kodeksu prawa kanonicznego, s. 27.

48 Kan. 498 KPK 1983.

${ }^{49}$ J. Borucki, Rada Kapłańska wyrazem udziału prezbiterów w życiu Kościoła partykularnego, s. 452.

${ }^{50}$ Kan. 499 KPK 1983.

51 T. Pawluk, Prawo kanoniczne według Kodeksu Jana Pawła II, s. 239.

${ }^{52}$ Kan. $500 \S 1$ KPK 1983. 
prawo biskup jest zobowiązany do wysłuchania opinii swojego senatu, a także niekiedy do uzyskania zgody ${ }^{53}$. Obecne przepisy kodeksowe nie nakładają w żadnym przypadku na biskupa diecezjalnego konieczności uzyskania zgody swojej rady ${ }^{54}$. Ostatni paragraf omawianego kanonu przypomina, że Rada kapłańska nie może działać bez swojego biskupa, który jako jedyny może ogłosić to, co zostało na niej uchwalone ${ }^{55}$.

Kolejnym zagadnieniem podjętym przez Prawodawcę kodeksowego jest kadencyjność. W kanonie $501 \S 1$, jest mowa o tym, iż poszczególne statuty określają okres członkostwa, natomiast cała rada albo chociaż tylko jej część była odnawiana co pięć lat. Jeśli chodzi o ten zapis, to dotyczy on członków z wyboru i nominacji, gdyż członkowie z urzędu pozostają w niej do czasu pełnienia swoje funkcji ${ }^{56}$. Postanowienia Konferencji Episkopatu Polski z 1985 r. podkreślą, że kadencja powinna trwać przez pięć lat $\mathrm{z}$ możliwością ponownego wyboru z zastrzeżeniem, że nie powinna trwać dłużej niż dwie kolejno po sobie następujące ${ }^{57}$. Kolejny paragraf omawianego kanonu mówi o ustaniu działalności Rady kapłańskiej podczas wakansu stolicy biskupiej oraz o obowiązku ponownego powołania przez biskupa nowej rady w ciągu roku od objęcia rządów w diecezji. Biskup diecezjalny posiada także prawo rozwiązania Rady kapłańskiej, gdyby ta nie wypełniała swojego zadania bądź też z powodu poważnych nadużyćs8.

Ostatni z omawianych kanonów traktuje o kolegium konsultorów. Jest to odrębny organ kolegialny, który cieszy się pewnego rodzaju stałością. Składa się z kapłanów wchodzących w skład senatu biskupa, których liczba wynosi między 6 a $12^{59}$. Kadencja kolegium konsultorów trwa 5 lat,

53 Problem „uzyskania zgody”, który stawał w sprzeczności z pojęciem Rady kapłańskiej jako głosu doradczego został rozwiązany przez Komisję ds. Rewizji Kodeksu, gdzie stwierdzono, iż można rozróżnić głos doradczy, który wyraża opinię i głos doradczy oznaczający wyrażenie zgody. W kilku przypadkach biskup jest zobowiązany przez Kodeks do wysłuchania opinii swojej Rady. Zob. J. Wroceński, Rola i zadania prezbiterium w życiu Kościoła partykularnego, s. 327-330.

\footnotetext{
${ }^{54}$ M. Sitarz, Rada Kapłańska i Kolegium Konsultorów, s. 389.

55 Kan $500 \$ 3$ KPK 1983.

${ }^{56}$ M. Sitarz, Rada Kapłańska i Kolegium Konsultorów, s. 390.

57 E. Górecki, Rada Kapłańska, s. 88.

${ }^{58}$ Kan. 501 \$\$ 2 i 3 KPK 1983.

${ }^{59}$ Kan. $502 \S 1$ KPK 1983.
} 
nawet gdyby któryś z członków przestał być w składzie rady kapłańskiej, nie przeszkodziło by to mu $\mathrm{w}$ pełnieniu funkcji w kolegium. Obradom tego organu przewodniczy zawsze biskup diecezjalny. W razie wakatu bądź niemożności pełnienia swojej funkcji, przewodniczy ten, kto tymczasowo zastępuje biskupa, a gdyby nie został jeszcze wybrany, wówczas członek najstarszy święceniami ${ }^{60}$.

Przepisy zawarte w Kodeksie, odnoszące się do Rady kapłańskiej, dają wiele miejsca prawodawcom partykularnym, aby mogli wprowadzić szczegółowe rozwiązania w kontekście swoich Kościołów lokalnych, uwzględniając ich specyfikę. W dalszej części ukazana zostanie troska biskupów włocławskich o wprowadzanie przepisów prawa powszechnego odnośnie do „nowego senatu biskupa” w strukturach swojej diecezji.

\section{RADA KAPŁAŃSKA W DIECEZJI WŁOCŁAWSKIEJ}

W czasach reformy Soboru Watykańskiego II, posługę pasterską w Diecezji włocławskiej pełnił biskup Antoni Pawłowski ${ }^{61}$. Jako biskup diecezjalny był bardzo zatroskany o wprowadzenie uchwał reformy soborowej na terenie swojego Kościoła partykularnego. Świadczy o tym fakt, iż w tym celu zwołał po zakończeniu soboru synod diecezjalny, który odbył się w 1967 roku i był jednocześnie pierwszym posoborowym synodem w Polsce ${ }^{62}$.

Biskup Pawłowski, zgodnie z poleceniem Dekretu o posłudze prezbiterów Prezbiterorum ordinis oraz motu proprio Pawła VI Ecclesiae sancte, 1 stycznia 1968 roku, utworzył pierwszą w diecezji włocławskiej Radę kapłańską. Tego samego dnia podpisał „Regulamin ramowy” będący załącznikiem do dekretu powołującego tę radę ${ }^{63}$.

${ }^{60}$ Kan. $502 \S 2$. J. Wroceński, Rada Kapłańska według Kodeksu prawa kanonicznego, s. 36-37.

${ }^{61}$ Biskup Antoni Pawłowski - biskup włocławski w latach 1953-1968.

${ }^{62}$ K. Rogala, Działalność synodalna $w$ diecezji włocławskiej po Soborze Watykańskim II jako odpowiedź na potrzebę recepcji uchwał soborowych w Kościele partykularnym, „Warszawskie Studia Pastoralne” 34 (2017) 1, s. 72.

${ }^{63}$ A. Pawłowski, Dekret ustanawiający Radę Kapłańską, 1.01 .1968 w: Archiwum Kurii włocławskiej. 
Regulamin Rady kapłańskiej zawierał podstawę prawną jej utworzenia, która odnosiła się do prawodawstwa soborowego i posoborowego. Znajdowały się w nim także wytyczne, aby nowopowstała rada, wykonując swoje prace, kierowała się wskazaniami zawartymi w tychże dokumentach. Do zadań rady w świetle omawianego regulaminu należało przedstawianie biskupowi opinii i potrzeb duchowieństwa, szczególnie $\mathrm{w}$ zakresie odnoszącym się do spraw personalnych i administracyjnych. Zgodnie z ówczesnym prawodawstwem powszechnym, regulamin określał skład jej członków. Nowo powstały organ miał stanowić reprezentację ogółu duchowieństwa całej diecezji. W skład wchodzili przedstawiciele różnych grup kapłańskich: dwóch dziekanów, jeden profesor seminarium diecezjalnego, czterech proboszczów, dwóch wikariuszy, przedstawiciel rezydentów (z grona rektorów, kapelanów i emerytów), przedstawiciel duchowieństwa zakonnego, oraz od trzech do pięciu kapłanów wybranych przez samego biskupa. Posiedzenia Rady kapłańskiej miały być zwoływane przez biskupa co do zasady dwa razy w roku z zastrzeżeniem, iż gdyby pojawiła się potrzeba mógł to czynić częściej. Zadaniem biskupa według regulaminu było, oprócz zwoływania posiedzenia rady, także zatwierdzanie porządku obrad oraz przewodniczenie osobiste lub przez wyznaczonego delegata. Porządkiem obrad zajmował się sekretarz, który został wyłoniony podczas pierwszego posiedzenia. Kadencja członków rady wynosiła trzy lata ${ }^{64}$.

Po tragicznej śmierci biskupa Pawłowskiego we wrześniu 1968 roku, rządy w Diecezji włocławskiej objął biskup Jan Zaręba ${ }^{65}$. Jego działalność, podobnie jak u poprzednika, była bardzo bogata i służyła celowi, jakim było dostosowanie prawa partykularnego do reformy soborowej, a także w latach późniejszych i po kodeksowej ${ }^{66}$. To właśnie biskup Zaręba był inicjatorem II Synodu Diecezji Włocławskiej, który odbył się w roku 1986. Niestety, jego śmierć, zgodnie z prawem, zawiesiła obrady synodalne $\mathrm{w}$ jego końcowej fazie ${ }^{67}$.

${ }^{64}$ Tenże, Regulamin ramowy Rady Kapłańskiej, 1.01.1968, tamże.

${ }^{65}$ Biskup Jan Zaręba - biskup pomocniczy w diecezji włocławskiej w latach 1963-1968, biskup diecezjalny w latach 1969-1986.

${ }^{66} \mathrm{~J}$. Borucki, Recepcja kościelnego prawa powszechnego w ustawodawstwie $i$ działalności duszpasterskiej Diecezji włocławskiej po Soborze Watykańskim II, Włocławek 2012, s. $46-49$.

${ }^{67}$ K. Rogala, Działalność synodalna $w$ diecezji włocławskiej po Soborze Watykańskim II jako odpowiedź na potrzebę recepcji uchwat soborowych w Kościele partykularnym, s. 83. 
Jeśli chodzi o działalność biskupa Zaręby w zakresie Rady kapłańskiej, to od samego początku swojej posługi postanowił poprawić wydany przez poprzednika regulamin. Odwołując się do dokumentów soborowych Christus Dominus (nr 28) i Presbyterorum ordinis ( $\mathrm{nr} 7$ ), a także do posoborowego dokumentu Ecclesiae sanctae, ustanowił nową Radę kapłańską ${ }^{68}$. Z powołaniem nowego senatu biskupa, związane było także nadanie nowego statutu dnia 22.05.1971 r. ${ }^{69}$

Porównując poprzedni „regulamin ramowy” i nowe statuty Rady kapłańskiej, to znajdują się tam niewielkie różnice. Jeśli chodzi o zadania rady, to podobnie jak wcześniej miała ona przedstawiać opinie i potrzeby duchowieństwa zwłaszcza w sprawach personalnych i administracyjnych, a także być głosem doradczym w ważnych dla diecezji sprawach. W statutach biskupa Zaręby zmieniły się także zapisy dotyczące składu Rady kapłańskiej. Została ona ustanowiona jako ogół prezbiterów diecezji, co odzwierciedlało się w następującym składzie: wikariusz generalny, rektor seminarium duchownego, dwóch dziekanów, po pięciu proboszczów i wikariuszy, przedstawiciel księży emerytów i przedstawiciel kapłanów zakonnych. Zebrania rady, tak jak w poprzednim regulaminie, miały być zwoływane dwa razy w roku. Nowością było to, iż wybierano dwóch sekretarzy spośród członków rady, odpowiedzialnych za przygotowywanie porządku obrad. Do biskupa należało zatwierdzenie tego porządku i przewodzenie obradom. Nie zmienił się zapis dotyczący kadencji, miała ona trwać przez 3 lata ${ }^{70}$.

Kolejnym pasterzem Kościoła włocławskiego został mianowany biskup Henryk Muszyński ${ }^{71}$. Kanonicznie objął diecezję 29.12.1987, a ingres do katedry włocławskiej odbył się 17.01.1988 . $^{72}$

${ }^{68} \mathrm{~J}$. Borucki, Recepcja kościelnego prawa powszechnego w ustawodawstwie i działalności duszpasterskiej Diecezji włocławskiej po Soborze Watykańskim II, s. 220-221.

${ }^{69}$ J. Zaręba Dekret ustanawiający Radę Kapłańską. 22.05.1971 r. w: Archiwum Kurii włocławskiej.

70 Tenże, Statuty Rady Kapłańskiej, 22.05.1971, tamże.

${ }^{71}$ Biskup Henryk Józef Muszyński - biskup włocławski w latach 1987-1992, później arcybiskup gnieźnieński i prymas Polski.

${ }^{72}$ J. Borucki, Recepcja kościelnego prawa powszechnego w ustawodawstwie i działalności duszpasterskiej Diecezji włocławskiej po Soborze Watykańskim II, s. 51. 
Niespełna dwa miesiące po ingresie, na podstawie przepisów KPK 1983, wydał ordynację wyborczą do rady kapłańskiej. Składała się ona z 6 punktów, w których szczegółowo określono przebieg wyborów. Zgodnie $\mathrm{z}$ nową ordynacją 15 kapłanów miało być mianowanych $\mathrm{z}$ wyboru. Prawo wyboru zarówno czynne, jak i bierne posiadali wszyscy ci, którzy wymienieni zostali w kanonie 498 KPK 1983. W gronie kapłanów z wyboru miało znajdować się po $5 \mathrm{z}$ każdego rejonu diecezji (włocławskiego, konińskiego i kalisko-sieradzkiego), po 3 proboszczów i po 2 wikariuszy. Wybory miały być przeprowadzane dwustopniowo, najpierw wybór 32 elektorów (po jednym przedstawicielu z każdego dekanatu), a następnie elektorzy wybierali członków Rady kapłańskiej ${ }^{73}$.

Biskup Muszyński mianował nową Radę kapłańską 9.04.1988, w skład której wchodziło 4 członków z urzędu, 15 członków z wyboru i 11 członków z nominacji biskupa. Okres kadencji wyznaczony został na 5 lat $^{74}$. Następnie opierając się na kanonie 502 KPK 1983 dnia 5.05.1988 r., został wydany dekret powołujący kolegium konsultorów, w skład którego wchodziło 10 członków Rady kapłańskiej. Ich kadencja również wynosiła 5 lat $^{75}$.

Następnym krokiem w działalności biskupa Muszyńskiego w odniesieniu do Rady kapłańskiej było ustanowienie nowego Statutu Rady kapłańskiej diecezji włocławskiej. Został on promulgowany 23.11.1989 roku. Oparty został na przepisach kodeksowych (kan. 495-501) oraz na Postanowieniach Konferencji Episkopatu Polski w sprawie Rad kapłańskich i kolegium konsultorów z 21.03.1985 roku.

Statut stanowił, iż Rada kapłańska diecezji włocławskiej reprezentująca prezbiterium jest jakby senatem biskupa diecezjalnego. Jako organ doradczy ma wspomagać działalność biskupa w celu osiągnięcia przez wiernych jak największego dobra. Podano także, iż skład rady liczy nie więcej niż 40 kapłanów. Członkami stałymi z racji pełnionego urzędu są: biskupi pomocniczy, wikariusze generalni, dziekan Kapituły Katedralnej, ekonom diecezjalny, dyrektor Wydziału Duszpasterskiego oraz rektor

${ }^{73}$ H. Muszyński, Ordynacja wyborcza do Rady Kapłańskiej Diecezji Włocławskiej, 16.03.1988, „Kronika Diecezji Włocławskiej” 71 (1988), s. 114-116.

${ }_{74}$ Tenże, Dekret powołujący Radę Kapłańską w Diecezji włocławskiej, 9.04.1988, tamże, s. 112-113.

75 Tenże, Dekret powołujący Kolegium Konsultorów, 5.05.1988 tamże, s. 113-114. 
diecezjalnego seminarium duchownego. Kolejną kategorią członków są kapłani wybierani zgodnie z ordynacją wyborczą i mają oni stanowić przynajmniej połowę całego składu, a ostatnia część to członkowie z nominacji biskupa diecezjalnego. Kadencję rady określono na 5 lat. Radę kapłańską zwołuje na posiedzenia biskup diecezjalny, spotkania odbywają się co do zasady dwa razy w roku (wiosną i jesienią), ale mogą odbywać się także według uznania biskupa. Każda nieobecność któregoś z członków powinna być usprawiedliwiona na piśmie. Obradom przewodniczy biskup diecezjalny osobiście, chyba że z ważnych powodów może zlecić to któremuś z biskupów pomocniczych. Rada wypowiada się na przedłożony przez biskupa wniosek bezwzględną większością głosów. Głosowanie jest tajne, chyba że na wniosek przewodniczącego zarządzone będzie głosowanie jawne. Do ważności głosowania potrzebna jest obecność większości członków. Tylko biskup diecezjalny decyduje o tym, co zostało uchwalone. Pozostałych członków obowiązuje tajemnica w zakresie przebiegu obrad ${ }^{76}$.

W roku 1992 papież Jan Paweł II dokonał reorganizacji administracyjnej Kościoła w Polsce. W wyniku tych działań, biskup Henryk Muszyński został mianowany arcybiskupem metropolitą gnieźnieńskim ${ }^{77}$. Jego następcą we Włocławku został mianowany ks. Bronisław Dembowski. Święcenia biskupie i ingres do katedry włocławskiej miały miejsce 20 kwietnia $1992 \mathrm{roku}^{78}$.

Jeśli chodzi o działalność biskupa Dembowskiego odnoszącą się do omawianego organu, to nie wprowadził on wiele zmian za czasów swojego pasterzowania. W promulgowanym przez niego II Synodzie Diecezji Włocławskiej z 1994 r. w 2 statutach jest wzmianka o Radzie kapłańskiej. Została ona zaliczona do organów służących pomocą biskupowi włocławskiemu w pełnieniu jego posługi, a wszyscy kapłani za jej pośrednictwem mogą przedstawić biskupowi to wszystko, co dotyczy potrzeb pracy duszpasterskiej i dobra diecezji ${ }^{79}$.

${ }^{76}$ Tenże, Statut Rady Kapłańskiej Diecezji włocławskiej, 24.11.1989, „Kronika Diecezji Włocławskiej”, 72 (1989), s. 226-228.

77 J. Borucki, Recepcja kościelnego prawa powszechnego w ustawodawstwie i działalności duszpasterskiej Diecezji włocławskiej po Soborze Watykańskim II, s. 51.

78 Biskup Bronisław Maria Dembowski - biskup włocławski w latach 1992-2003.

${ }^{79}$ Drugi Synod Diecezji Włocławskiej, Włocławek 1994, statuty 283, 284. 
Na początku swojej posługi biskup Dembowski zatwierdził nową ordynację wyborczą, która różniła się od poprzedniej ilością kapłanów z wyboru. Z racji utworzenia nowej diecezji kaliskiej, z okręgu duszpasterskiego kalisko-sieradzkiego został tylko sieradzki. Dlatego to w nowej ordynacji wyborczej z tego rejonu wybierano tylko 3 kapłanów (2 proboszczów i jednego wikariusza), a nie jak wcześniej 5. Stąd liczba kapłanów z wyboru wynosiła 13 a nie 15 . Pozostałe zapisy nie uległy znacznym zmianom ${ }^{80}$. Nowa ordynacja wyborcza została zatwierdzona 26.10.1992 roku, a dwa dni później zostało wydane zarządzenie dotyczące wyborów. W zarządzeniu tym pasterz diecezji potwierdził, że utworzony w 1989 roku Statut Rady Kapłańskiej Diecezji Włocławskiej jest nadal obowiązującym $^{81}$. Powołując się na przepisy KPK 1983, statut z roku 1989 i ordynację wyborczą z 1992 roku, biskup Bronisław Dembowski powołał dekretem z dnia 12.02.1993 r. nową Radę kapłańską diecezji włocławskiej ${ }^{82}$, a 23.02.1993 r. kolegium konsultorów ${ }^{83}$. Kadencja obu organów była pięcioletnia, dlatego ponownego ich ustanowienia dokonał we wrześniu $1998 \mathrm{r}^{84}$.

Dnia 25 marca 2003 r., Ojciec święty Jan Paweł II przyjął rezygnację z obowiązków pasterza diecezji włocławskiej biskupa Bronisława Dembowskiego, z racji ukończenia przez niego 75. roku życia. Tym samym mianował ks. Wiesława Meringa ${ }^{85}$ - rektora WSD w Pelplinie, biskupem diecezjalnym diecezji włocławskiej. Święcenia biskupie i ingres do katedry we Włocławku odbyły się 26.04.2003 r.

Pierwszym działaniem biskupa Meringa w kwestii omawianego organu kolegialnego było powołanie dekretem z dnia 21.12.2003 r. nowej Rady kapłańskiej diecezji włocławskiej i kolegium konsulto-

${ }^{80}$ B. Dembowski, Ordynacja wyborcza dla Rady Kapłańskiej Diecezji Włocławskiej, 26.10.1992, „Kronika Diecezji Włocławskiej” 75 (1992), s. 187-189.

${ }^{81}$ Tenże, Zarządzenie dotyczace wyborów, 28.10.1992, tamże, s. 189.

${ }^{82}$ Tenże, Dekret powołujący Radę Kapłańską, 12.02.1993, „Kronika Diecezji Włocławskiej” 76 (1993), s. 18-19.

${ }^{83}$ Tenże, Dekret powołujący Kolegium Konsultorów, 23.02.1993, tamże, s. 20-21.

${ }_{84}$ Tenże, Nominacje i odznaczenia, „Kronika Diecezji Włocławskiej” 81(1998), s. $389-391$.

${ }^{85}$ Biskup Wiesław Alojzy Mering - biskup włocławski od 2003 roku. 
rów ${ }^{86}$. Odbyło się to według wcześniej obowiązującej ordynacji wyborczej i regulaminu.

Pod koniec kadencji obu organów, pasterz diecezji ustanowił nowy Statut Rady Kapłańskiej Diecezji Włocławskiej oraz wydał nową ordynację wyborczą do tegoż gremium. Jeśli chodzi o regulamin, to znajduje się w nim kilka różnic względem tego wydanego przed dziewiętnastu laty. Pierwszą zasadniczą różnicą jest zmniejszenie liczby członków, wyrażone w zapisie, iż rada liczy nie więcej niż 30 kapłanów. Zmienił się także skład członków z urzędu, w obecnym regulaminie są to: biskupi pomocniczy, wikariusze generalni, wikariusz sądowy, wikariusze biskupi, ekonom diecezjalny, rektor seminarium duchownego oraz kanclerz kurii. Istotną zmianą jest także zapis, iż sekretarzem rady kapłańskiej jest każdorazowy kanclerz Kurii Diecezjalnej. W poprzednim regulaminie członkowie rady wybierali go ze swojego grona ${ }^{87}$. To najistotniejsze różnice między najnowszym regulaminem, a tym wydanym przez biskupa Muszyńskiego w 1989 roku.

Jeśli chodzi o zmiany $\mathrm{w}$ ordynacji wyborczej, to odniesieniem będzie ordynacja wydana przez biskupa Dembowskiego w 1992 roku. W najnowszej ordynacji powrócono do wcześniejszej liczby kapłanów z wyboru, która wynosi 15. Zmieniła się tylko proporcja, jeśli chodzi o okręgi duszpasterskie. Z rejonu włocławskiego wybieranych jest 7 kapłanów (4 proboszczów i 3 wikariuszy), rejony koniński i sieradzki pozostały bez zmian. Nastąpiła też zmiana ilości elektorów, co było konsekwencją reorganizacji administracyjnej diecezji, ale zasada pozostała ta sama, iż z każdego dekanatu jest jeden elektor. Podobnie jak miało to miejsce w nowym regulaminie, występuje zapis, iż nie wybiera się sekretarza do przeprowadzenia wyborów, gdyż jest nim kanclerz kurii ${ }^{88}$.

Powołując się na przepisy kodeksowe oraz nowy regulamin i ordynację wyborczą, biskup Mering ustanowił kolejną Radę kapłańską

${ }^{86}$ W. Mering, Dekret powołujący Radę Kapłańską Diecezji Włocławskiej; Dekret powołujący Kolegium Konsultorów Diecezji Włocławskiej, 21.12.2003. „Kronika Diecezji Włocławskiej” 86 (2003), s. 734-735.

87 Tenże, Statut Rady Kapłańskiej Diecezji Włocławskiej, 9.11.2008, „Miesięcznik Diecezji Włocławskiej” 91 (2008), s. 1115-1119.

${ }_{88}$ Tenże, Ordynacja wyborcza do Rady Kapłańskiej Diecezji Włocławskiej, 9.11.2008, tamże, s. 1119-1122. 
22.12.2008 r. ${ }^{89}$, a po wygaśnięciu jej kadencji następną 27.12.2013 r. ${ }^{90}$ Wraz z powołaniem Rady kapłańskiej, biskup powoływał także kolegium konsultorów. Jeśli chodzi o dekrety powołujące, to w 2003 i w 2008 roku były wydane w tym samym dniu, co te o radzie ${ }^{91}$. Natomiast ostatniego powołania ośmioosobowego kolegium konsultorów dokonał 22.01.2014 roku $^{92}$.

Od tego czasu w diecezji włocławskiej nie nastąpiły żadne zmiany dotyczące omawianego organu konsultacyjnego biskupa, którym jest Rada kapłańska.

\section{ZAKOŃCZENIE}

Niniejsze opracowanie ukazuje, jak od czasu Soboru Watykańskiego II rozwijała się w prawodawstwie kościelnym nowa instytucja Rada kapłańska, zaliczana do organów konsultacyjnych w Kościele partykularnym. Prawodawca powszechny daje wiele miejsca rządcom poszczególnych Kościołów partykularnych, aby dostosować szczegółowe rozwiązana $\mathrm{w}$ zakresie omawianego organu do specyfiki i potrzeb konkretnej wspólnoty lokalnej. Przeprowadzone badania pozwalają odpowiedzieć na postawione we wstępie pytanie dotyczące czy i jak w Kościołach partykularnych została podjęta działalność w celu wprowadzania i funkcjonowania tego nowego organu kolegialnego. Analiza zebranego materiału pozwala dostrzec troskę biskupów włocławskich o rozwój i wdrażanie przepisów prawa powszechnego dotyczących rady kapłańskiej na terenie swojej diecezji. Już w dwa lata po zakończeniu soboru została powołana pierwsza w historii Kościoła włocławskiego Rada kapłańska. Dostrzegalna jest także troska biskupów na przestrzeni lat o dostosowywanie statutów

89 Tenże, Dekret powołujący Radę Kapłańską Diecezji Włocławskiej, „Miesięcznik Diecezji Włocławskiej" 92 (2009), s. 99-100.

90 Tenże, Dekret powołujący Radę Kapłańska Diecezji Włocławskiej, „Miesięcznik Diecezji Włocławskiej” 97 (2014), s. 38-39.

${ }^{91}$ J. Gręźlikowski, Działalność ustawodawcza Biskupa Wiesława Alojzego Meringa w latach 2010-2015, „Studia Włocławskie” 17 (2015), s. 49.

92 W. Mering, Dekret powołujący Kolegium Konsultorów Diecezji Włocławskiej, „Miesięcznik Diecezji Włocławskiej” 97 (2014), s. 127-128. 
i ordynacji wyborczych do warunków i zmian administracyjnych na terenie diecezji.

\section{BIBLIOGRAFIA}

Borucki J., Kapituła katedralna i Rada Kapłańska - stary i nowy senat biskupa diecezjalnego, „Studia Włocławskie” 9 (2009), s. 244-256.

Borucki J., Rada Kapłańska wyrazem udziału prezbiterów w życiu Kościoła partykularnego, „Ateneum Kapłańskie” 134 (2000), z. 2 (546), s. 444-458.

Borucki J., Recepcja kościelnego prawa powszechnego w ustawodawstwie $i$ działalności duszpasterskiej Diecezji włocławskiej po Soborze Watykańskim II, Włocławek 2012.

Codex Iuris Canonici, auctoritate Joannis Pauli pp. II promulgatus. Kodeks prawa kanonicznego, przekład polski zatwierdzony przez Konferencję Episkopatu, Poznań 1984.

Dembowski B., Dekret powołujący Kolegium Konsultorów, 23.02.1993, „Kronika Diecezji Włocławskiej" 76 (1993), s. 20-21.

Dembowski B., Dekret powołujacy Radę Kapłańska, 12.02.1993, „Kronika Diecezji Włocławskiej" 76 (1993) s. 18-19.

Dembowski B., Nominacje i odznaczenia, „Kronika Diecezji Włocławskiej” 81 (1998), s. $389-391$.

Dembowski B., Ordynacja wyborcza dla Rady Kapłańskiej Diecezji Włocławskiej, 26.10.1992, „Kronika Diecezji Włocławskiej” 75 (1992), s. 187-189.

Dembowski B., Zarzadzenie dotyczące wyborów, 28.10.1992, „Kronika Diecezji Włocławskiej" 75 (1992), s. 189.

Drugi Synod Diecezji Włocławskiej. Statuty., Włocławek 1994.

Dyduch J., Obowiazki i prawa wiernych świeckich w prawodawstwie soborowym, Kraków 1985.

Fąka M., Rada kapłańska nowym senatem biskupa diecezjalnego, „Prawo Kanoniczne” 21 (1978) 3-4, s. 41-69.

Glemp J., Problem identyfikacji Kościoła lokalnego i partykularnego, „Prawo Kanoniczne” 21 (1978) 3-4, s. 23-39.

Góralski W., Struktury synodalne i kolegialne w Kościele partykularnym według KPK Jana Pawła II, „Studia Płockie” XIV (1986), s. 54-68.

Górecki E., Rada Kapłańska, w: Struktury kolegialne w Kościele partykularnym, J. Krukowski, T. Rozkrut (red.), Tarnów 2004, s. 81-93.

Gręźlikowski J., Działalność ustawodawcza Biskupa Wiesława Alojzego Meringa w latach 2010-2015, „Studia Włocławskie” 17 (2015), s. 31-54.

Krukowski J., Administracja w Kościele, Zarys kościelnego prawa administracyjnego, Lublin 1985.

Krukowski J., Kolegialne organy konsultacyjne w Kościołach partykularnych, w: Struktury kolegialne w Kościele partykularnym, J. Krukowski, T. Rozkrut (red.), Tarnów 2004, s. 21-31. 
Mering W., Dekret powołujący Kolegium Konsultorów Diecezji Włocławskiej, „Miesięcznik Diecezji Włocławskiej” 97 (2014), s. 127-128.

Mering W., Dekret powołujący Radę Kapłańską Diecezji Włocławskiej, „Miesięcznik Diecezji Włocławskiej” 92 (2009), s. 99-100.

Mering W., Dekret powołujący Radę Kapłańską Diecezji Włocławskiej, „Miesięcznik Diecezji Włocławskiej” 97 (2014), s. 38-39.

Mering W., Dekret powołujący Radę Kapłańska Diecezji Włocławskiej; Dekret powołujacy Kolegium Konsultorów Diecezji Włocławskiej, 21.12.2003. „Kronika Diecezji Włocławskiej” 86 (2003), s. 734-735.

Mering W., Ordynacja wyborcza do Rady Kapłańskiej Diecezji Włocławskiej, 9.11.2008, „Miesięcznik Diecezji Włocławskiej” 91 (2008), s. 1119-1122.

Mering W., Statut Rady Kapłańskiej Diecezji Włocławskiej, 9.11.2008, „Miesięcznik Diecezji Włocławskiej” 91 (2008), s. 1115-1119.

Muszyński H., Dekret powołujący Kolegium Konsultorów, 5.05.1988, „Kronika Diecezji Włocławskiej” 71 (1988), s. 113-114.

Muszyński H., Dekret powołujący Radę Kapłańska w Diecezji włocławskiej, 9.04.1988, „Kronika Diecezji Włocławskiej” 71 (1988), s. 112-113.

Muszyński H., Ordynacja wyborcza do Rady Kapłańskiej Diecezji Włocławskiej, 16.03.1988, „Kronika Diecezji Włocławskiej” 71 (1988), s. 114-116.

Muszyński H., Statut Rady Kapłańskiej Diecezji włocławskiej, 24.11.1989, „Kronika Diecezji Włocławskiej”, 72 (1989), s. 226-228.

Pawłowski A., Dekret ustanawiający Radę Kapłańską, 1.01 .1968 w: Archiwum Kurii włocławskiej.

Pawłowski A., Regulamin ramowy Rady Kapłańskiej, 1.01 .1968 w: Archiwum Kurii włocławskiej.

Pawluk T., Prawo kanoniczne według Kodeksu Jana Pawła II, t. 2, Olsztyn 1986.

Pieronek T., Rada Kapłańska wyrazem soborowej odnowy prezbiterium, „Prawo Kanoniczne" 12 (1969) 3-4, s. 3-28.

Rogala K., Działalność synodalna $w$ diecezji włocławskiej po Soborze Watykańskim II jako odpowiedź na potrzebę recepcji uchwał soborowych w Kościele partykularnym, „Warszawskie Studia Pastoralne” 34 (2017) 1, s. 71-88.

Sitarz M., Rada Kaptańska i Kolegium Konsultorów, w: Komentarz do Kodeksu prawa kanonicznego, Tom II cz. 1, Księga II. Lud Boży, J. Krukowski (red.), Poznań 2005.

Sobór Watykański II, Dekret o misyjnej działalności Kościoła Ad genteks divinitus, 7.12.1965, w: Sobór Watykański II, Konstytucje, Dekrety, Deklaracje; tekst polski, Poznań 2002, s. 433-471.

Sobór Watykański II, Dekret o pasterskich zadaniach biskupów w Kościele Christus Dominus, 28.10.1965, w: Sobór Watykański II, Konstytucje, Dekrety, Deklaracje; tekst polski, Poznań 2002, s. 236-258.

Sobór Watykański II, Dekret o posłudze i życiu prezbiterów Presbyterorum ordinis, 7.12.1965, w: Sobór Watykański II, Konstytucje, Dekrety, Deklaracje; tekst polski, Poznań 2002, s. 478-508. 
Sobór Watykański II, Konstytucja dogmatyczna o Kościele, Lumen gentium, 21.11.1964, w: Sobór Watykański II, Konstytucje, Dekrety, Deklaracje; tekst polski, Poznań 2002, s. 104-166.

Wójcik W., Rada Kapłańska, „Ateneum Kapłańskie” 71 (1968), s. 221-233.

Wroceński J., Rada Kapłańska według Kodeksu prawa kanonicznego, „Prawo Kanoniczne” 36 (1993) 1-2, s. 19-40.

Wroceński J., Rola i zadania prezbiterium w życiu Kościoła partykularnego, Warszawa 1998 Zaręba J. Dekret ustanawiający Radę Kapłańską. 22.05.1971 r. w: Archiwum Kurii włocławskiej.

Zaręba J., Statuty Rady Kapłańskiej, 22.05.1971 w: Archiwum Kurii włocławskiej. 